\title{
Siderophore Production of the Hg-Resistant Endophytic Bacteria Isolated from Local Grass in the Hg-Contaminated Soil
}

\author{
Reni Ustiatik ${ }^{*}$, Yulia Nuraini ${ }^{2}$, Suharjono ${ }^{3}$, Eko Handayanto ${ }^{2}$ \\ 1 Doctoral Program of Agricultural Science, Faculty of Agriculture, Brawijaya University, \\ Jl. Veteran Malang 65145, Indonesia \\ 2 Soil Science Department, Faculty of Agriculture, Brawijaya University, J. Veteran Malang 65145, Indonesia \\ 3 Department of Biology, Faculty of Science, Brawijaya University, J. Veteran Malang 65145, Indonesia \\ *Corresponding author's e-mail: reniustiatik@gmail.com
}

\begin{abstract}
Mercury ( $\mathrm{Hg}$ )-contaminated soil remediation has become an urgent necessity due to its harmful effect on the environment and living organisms. The use of plant-endophyte partnership for phytoremediation demonstrates an excellent opportunity for cleaning heavy metal contaminated soil. This study aimed to screen and characterize the phenotype of the Hg-resistant endophytic bacteria from local grasses (Cynodon dactylon and Eleusine indica) in the Hg-contaminated soil of West Nusa Tenggara, Indonesia with siderophore-producing traits. Siderophore production of bacteria was qualitatively tested using overlay-chrome azurol S (O-CAS) medium and quantitatively tested using the succinic acid medium. The assay was designed using a Completely Randomized Factorial Design consisting of two factors, i.e., isolate type and incubation time with three replicates. The selected isolates were pathogenicity tested, then they were phenotypically characterized. All tested isolates showed a positive result on changing O-CAS medium color from blue to yellow/brown that indicated hydroxamate type of siderophore. The highest siderophore production was achieved at 72 hours of incubation, by the EI5 and EI6 isolates $(62.90 \%$ and $35.31 \%$, respectively). In turn, the CD6, EI5 and EI6 isolates achieved high siderophore production at a short incubation period (48 hours). However, during the hemolysis test, only the CD6 and EI6 isolates were not pathogenic. The CD6 and EI6 isolates would be used for phytoremediation on $\mathrm{Hg}$-contaminated soil in the future study. On the basis of the 16S rDNA analysis, it was shown that the CD6 isolate was Jeotgalicoccus huakuii and the EI6 isolate was Bacillus amyloliquefaciens.
\end{abstract}

Keywords: endophytic bacteria, growth-promoter, metal-chelator, siderophore-producing, Hg phytoremediation.

\section{INTRODUCTION}

Mercury $(\mathrm{Hg})$ is a heavy metal that is persistent and difficult to remove if it pollutes the soil (Padmavathiamma and Li 2007; Tangahu et al. 2011; Xu et al. 2015). The primary source of $\mathrm{Hg}$ contamination in soil worldwide is artisanal and small-scale gold mining (ASGM) (Xu et al. 2015). The mercury contamination from ASGM (such as in Indonesia) occupies more than half of all $\mathrm{Hg}$ emitter sectors, approximately $57.5 \%$ of the national $\mathrm{Hg}$ emission (Dewi and Ismawati 2015). Tailing (mining waste) from ASGM in Indonesia is generally deposited on soil without treatment (Trihadiningrum et al. 2019). Remediation of the heavy metal contaminated sites has become an urgent necessity (Manoj et al. 2020) due to their harmful effect on the environment and high toxicity to living organisms (Leung et al. 2013), mainly when it contaminates the agro-ecosystem and food production areas because heavy metals can be taken up by plants or fungi (such as mushrooms) and directly contaminate the food chain (Falandysz et al. 2015; Shao et al. 2020). Phytoremediation is the most promising approach among other remediation approaches due to costefficient and environmentally friendly (Ruiz et al. 2011; Tangahu et al. 2011).

Phytoremediation uses plants and their associated microbes to clean up the soil from heavy 
metals (Kong and Glick 2017). The bacteria isolated from the heavy metal contaminated areas tend to develop heavy metal resistance and enhance phytoremediation (Ustiatik et al. 2020), which provides good prospects for cleaning the contaminated sites in the future (Sheng et al. 2008; Dash and Das 2014). Moreover, phytoremediation using local/indigenous plants and bacteria tends to be safe because it does not introduce new species that are potentially invasive and harmful to the local ecosystem (Leguizamo et al. 2017). The plant-endophyte partnership demonstrates an excellent opportunity toward the remediation of heavy metal contaminated soil (Ijaz et al. 2016). Endophytic bacteria assist their host plant in withstanding the stress induced by heavy metals (Jabeen et al. 2016). A previous study demonstrated that the application of bacteria with plant growthpromoting traits positively affected the plant biomass, supporting and enhancing arsenic (As) and Hg phytoextraction (Franchi et al. 2017). Endophytic bacteria reside within plant tissues and hold essential roles, especially in plant-growth regulation (Yan et al. 2018; Zhang et al. 2019). The bacteria do not only support the plant growth but also indirectly overcome the harmful effect of heavy metals by modulating the phytohormone levels such as producing cytokinins, gibberellin and indole acetic acid (IAA). Moreover, facilitating nutrients acquisition, such as nitrogen fixation, phosphate solubilization and siderophore production (iron sequestration) (Glick 2012).

Siderophores that are produced by bacteria, fungi and graminaceous plants under low iron conditions (Schütze et al. 2015) have recently been used to reduce the level of metal contamination in the environment, specifically from soil and water (Ahmed and Holmström 2014; Schütze et al. 2015; Ali and Vidhale 2016). Siderophores are organic compounds with low molecular masses (500-1500 Da) the primary function of which is to chelate the ferric iron $[\mathrm{Fe}(\mathrm{III})]$ from different habitats (terrestrial and aquatic) and thereby make it available for microbial and plant cells (Ahmed and Holmström 2014; Schütze et al. 2015). The benefits of inoculating siderophore-producing bacteria (SPB) for phytoremediation of contaminated soils $(\mathrm{Cd}$, $\mathrm{Pb}, \mathrm{Cu}$, and $\mathrm{Ni}$ ) have been successfully demonstrated. The bacteria support plant survival and growth by alleviating the metal toxicity and supplying the plant with nutrients, particularly iron (Rajkumar et al. 2010). Siderophores in heavy metal phytoremediation act as an effective metal solubilizer, thus increasing metal mobility (such as $\mathrm{Cd}, \mathrm{Cu}, \mathrm{Ni}, \mathrm{Pb}$ and $\mathrm{Zn}$ ). In addition, siderophores act as metal chelators, for example, the siderophore that is produced by Pseudomonas aeruginosa could chelate a wide range of metals such as $\mathrm{Cd}^{2+}, \mathrm{Co}^{2+}, \mathrm{Cr}^{2+}, \mathrm{Cu}^{2+}, \mathrm{Mn}^{2+}$ and $\mathrm{Hg}^{2+}$ (Ahmed and Holmström 2014). This study aimed to screen and characterize the phenotype of Hg-resistant endophytic bacteria from local grasses in the $\mathrm{Hg}$-contaminated soil with siderophore-producing traits to select the most prospective isolates for phytoremediation of the Hg-contaminated soil in the future study.

\section{MATERIALS AND METHODS}

\section{Source of isolate}

The bacteria isolates used in this research were from the previous study by Ustiatik (2019). The bacteria were isolated from local grasses (Cynodon dactylon and Eleusine indica) in the Hg-contaminated soil at Jonggat Sub-Regency, Central Lombok Regency, West Nusa Tenggara ( $8^{\circ} 38^{\prime} 26^{\prime \prime} \mathrm{S}$ and $116^{\circ} 13$ '23" E). There were thirteen Hg-resistant endophytic bacteria (Cynodon dactylon: $\mathrm{CD} 1, \mathrm{CD} 2, \mathrm{CD} 3, \mathrm{CD} 4, \mathrm{CD} 5, \mathrm{CD} 6$, and CD7 isolates; Eleusine indica: EI1, EI2, EI3, EI4, EI5, and EI6 isolates). Five isolates of the bacteria survived in Nutrient Agar (NA) containing more than $250 \mathrm{mg} / \mathrm{L} \mathrm{HgCl}_{2}$ (CD2, CD6, CD7, EI5, and EI6 isolates).

\section{Qualitative siderophore production assay}

Screening of siderophore production by the Hg-resistant endophytic bacteria was carried out using O-CAS medium (Overlay Chrome Azurol $\mathrm{S})$ according to the modified method by PérezMiranda et al. (2007). The popular CAS medium for siderophore detection based on chrome azurol S by Schwyn and Neilands (1987) is not suitable for all bacteria. The medium is toxic for some bacteria and inhibits the bacteria growth (PérezMiranda et al. 2007). The composition of O-CAS medium in 1 liter is Chrome Azurol S (CAS) $60.5 \mathrm{mg}$, hexadecyl trimethyl ammonium bromide (HDTMA) $72.9 \mathrm{mg}, 1 \mathrm{mM} \mathrm{FeCl}_{3} \cdot 6 \mathrm{H}_{2} \mathrm{O}$ in $10 \mathrm{mM}$ $\mathrm{HCl} 10 \mathrm{~mL}$, Piperazine-1,4-bis (2-ethane sulfonic acid) (PIPES) $30.24 \mathrm{~g}$ and agarose $(0.9 \%, \mathrm{w} / \mathrm{v})$. A mixture of CAS, HDTMA and $1 \mathrm{mM} \mathrm{FeCl}{ }_{3} \cdot 6 \mathrm{H}_{2} \mathrm{O}$ 
in $10 \mathrm{mM} \mathrm{HCl}$ was dissolved using sterile deionized water and produced a dark blue solution. The solution is called CAS Reagent. This reagent is sensitive to $\mathrm{pH}$ and high temperature. The mixture of PIPES and agarose were sterilized using an autoclave at $121^{\circ} \mathrm{C}$ for 15 minutes. The mixture was added to the CAS Reagent when the solution temperature is below $50^{\circ} \mathrm{C}$.

The tested isolates were inoculated onto NA (Nutrient Agar) medium. After incubation for 24 hours, $10 \mathrm{~mL}$ of O-CAS medium was added to the surface of NA medium (overlay) where the bacteria had grown. The color change in the OCAS medium was observed after incubation for 15-30 minutes. The color change from blue to purple indicates a catechol type of siderophore, while the color change from blue to yellow to orange/brownish indicates a hydroxamate type of siderophore (Jenifer and Sharmili 2015). The negative control was NA medium without bacteria inoculation, while the positive control was Pseudomonas aeruginosa, which was reported as a hydroxamate type of siderophore-producing bacterium (Jenifer and Sharmili 2015; Sasirekha and Srividya 2016). The experiment was performed in three replicates.

\section{Quantitative siderophore production assay and growth curve preparation}

Quantitative siderophore production assay was carried out according to the method by Jenifer and Sharmili (2015) using Completely Randomized Factorial Design that consisted of two factors, namely isolate type (CD2, CD6, CD7, EI5 and EI6 isolates) and incubation time $(0,24$, 48 and 72 hours). Each treatment was performed in three replicates.

The starter of bacteria was grown in a succinic acid medium. The succinic acid medium composition in 1 liter is $\mathrm{K}_{2} \mathrm{HPO}_{4} 6 \mathrm{~g}, \mathrm{KH}_{2} \mathrm{PO}_{4}$ $3 \mathrm{~g}, \mathrm{MgSO}_{4} \cdot 7 \mathrm{H}_{2} \mathrm{O} 0.2 \mathrm{~g}$, [NH4] $]_{2} \mathrm{SO}_{4} 1 \mathrm{~g}$ and succinic acid $4 \mathrm{~g}$. The $\mathrm{pH}$ of medium was adjusted to neutral conditions (6.8-7) by adding $\mathrm{NaOH}$ 2N (Meyer and Abdallah 1978; Bharucha et al. 2013). The bacteria cultures were incubated in a shaker $\left(120 \mathrm{rpm}, 30^{\circ} \mathrm{C}\right)$ for 24 hours. Five milliliters of bacteria starter $\left(7.44 \times 10^{6}\right.$ cells $\left./ \mathrm{mL}\right)$ were inoculated into $50 \mathrm{~mL}$ of succinic acid medium and incubated in a shaker $\left(120 \mathrm{rpm}, 30^{\circ} \mathrm{C}\right)$ for 72 hours. The growth curve was based on the optical density value and measured using a UV-Vis Spectrophotometer at $620 \mathrm{~nm}$. The bacteria cell density was measured at $0,24,48$, to 72 hours by sub-sampling of bacteria culture $(3 \mathrm{~mL})$ in each treatment and standardized using the standard curve of each tested isolates.

A sub-sample $(2 \mathrm{~mL})$ of bacteria culture was collected at $0,24,48$ and 72 hours and centrifuged at $10,000 \mathrm{rpm}\left(4^{\circ} \mathrm{C}\right)$ for 10 minutes. The CAS Reagent was added into supernatant $(1: 1, \mathrm{v} / \mathrm{v})$, then incubated at room temperature for $30 \mathrm{~min}$ utes and measured using a UV-Vis Spectrophotometer at $630 \mathrm{~nm}$ (Jenifer and Sharmili 2015). The uninoculated succinic acid medium was used as a control negative. Siderophore production of tested isolates was compared with Pseudomonas aeruginosa (control positive) (Pérez-Miranda et al. 2007; Jenifer and Sharmili 2015; Sasirekha and Srividya 2016). The percentage of siderophore units was estimated as Eq. (1).

$\%$ siderophore unit $=[(\mathrm{Ar}-\mathrm{As}) / \mathrm{Ar}] \times 100$

where: $A r$ is the absorbance of reference (CAS reagent + uninoculated medium) and As is the absorbance of the sample (CAS reagent + cell-free supernatant).

\section{Pathogenicity test}

Screening of non-pathogenic isolates was carried out based on blood agar hemolysis. One loop of the tested isolates was streaked onto blood agar then incubated for 24 hours $\left(28{ }^{\circ} \mathrm{C}\right)$. The blood agar medium is NA, which was enriched with $5 \%$ (v/v) sheep blood (pH 7.4) (Murtado et al. 2020). A positive result is indicated by a clear zone surrounding the colony ( $\beta$ hemolysis) or greenish halo around the bacteria growth ( $\alpha$ hemolysis) (Cappuccino and Natalie 2014).

\section{Phenotypic characterization}

The selected bacteria were characterized phenotypically, including spore formation and motility. Spore formation was observed by spore staining with malachite green. Motility was observed using SIM agar. The bacteria starters were grown on Tryptic Soy Broth (TSB) and incubated for 24 hours, then stabbed onto the medium. A positive result is indicated by medium turbidity. The growth of flagellated bacteria is unrestricted to the inoculation pathway because the bacteria are motile, while the growth of non-motile bacteria is 
restricted to the inoculation pathway (Cappuccino and Natalie 2014).

The selected isolates were tested for biochemical characteristics, according to Cappuccino and Natalie (2014) that consist of: oxidation, nitrate reduction, catalase, coagulase, antibiotic (novobiocin) sensitivity, starch and casein hydrolysis, and carbohydrate fermentation. The biochemical characteristics of the selected isolates were also tested using biochemical identification kits (Oxoid MICROBACT GNB) 12A/B, which consisted of lysine, ornithine, $\mathrm{H}_{2} \mathrm{~S}$, glucose, mannitol, xylose, ONPG (o-nitrophenyl- $\beta$-d-galactopyranoside), indole, urease, VP (Voges-Proskaüer reaction), citrate, TDA (Tryptophan deaminase); gelatin, malonate, inositol, sorbitol, rhamnose, sucrose, lactose, arabinose, adonitol, raffinose, salicin, and arginine. The test was carried out according to the kit instructions. The color change indicates positive results according to the substrate table in the kit manual (Khan et al. 2018).

\section{Data analysis}

The data were analyzed using One Way ANOVA at $5 \%$ significant level using the SPSS software (trial version). The relationships among treatment grouping were determined with the Tukey test at 5\% significance level. The phenotypic characteristics data were profile matched with identified species of 16S rDNA in Bergey's Manual of Determinative Bacteriology.

Table 1. Qualitative siderophore production assay

\begin{tabular}{|c|c|c|c|}
\hline \multirow{2}{*}{ Isolate } & \multirow{2}{*}{$\begin{array}{c}\text { Siderophore } \\
\text { production }\end{array}$} & \multicolumn{2}{|c|}{ Siderophore type } \\
\cline { 3 - 4 } & Hydroxamate & Catechol \\
\hline CD1 & + & $\checkmark$ & - \\
\hline CD2 & + & $\checkmark$ & - \\
\hline CD3 & + & $\checkmark$ & - \\
\hline CD4 & + & $\checkmark$ & - \\
\hline CD5 & + & $\checkmark$ & - \\
\hline CD6 & + & $\checkmark$ & - \\
\hline CD7 & + & $\checkmark$ & - \\
\hline El1 & + & $\checkmark$ & - \\
\hline El2 & + & $\checkmark$ & - \\
\hline El3 & + & $\checkmark$ & - \\
\hline El4 & + & $\checkmark$ & - \\
\hline El5 & + & $\checkmark$ & - \\
\hline El6 & + & $\checkmark$ & - \\
\hline
\end{tabular}

Note: $(+)=$ positive siderophore production; $(-)=$ negative siderophore production; $\mathrm{CD}=$ Cynodon dactylon; EI = Eleusine indica; $(\checkmark)=$ positive type of siderophore

\section{RESULTS AND DISCUSSION}

\section{Qualitative siderophore production}

All tested isolates showed positive results as siderophore-producing bacteria (Table 1). The qualitative siderophore production assay showed that O-CAS medium color changed from blue to yellow/brown after incubation for 30 minutes (Figure 1), indicating that the bacteria produce hydroxamate type of siderophore. This result is contrary to the previous study that endophytic bacteria are dominant in catechol type of siderophore production. However, a qualitative assay for siderophore production with the CAS medium in the same study showed that all tested bacteria produced only hydroxamate type siderophores, which is in line with the current study (Grobelak and Hiller 2017). Siderophores are characterized depending on the functional group and divided into three main families, i.e. hydroxamates, catecholates and carboxylates (Ahmed and Holmström 2014). Most bacteria produce hydroxamate type of siderophore (Ali and Vidhale 2016). Hydroxamate type of siderophores is prevalent in acidic soils. However, neutral to alkaline soils support the production of catecholate siderophores (Rajkumar et al. 2010). A previous study proved that Pseudomonas aeruginosa (a control positive of this study) produces hydroxamate type of siderophore at the $\mathrm{pH}$ values in the range of 6-9, with optimum production at $\mathrm{pH} 6$ (Manwar et al. 2004). The $\mathrm{pH}$ of O-CAS medium for screening siderophore-producing bacteria in this study was 6.8 , which affected the tested bacteria of siderophore type. The tested bacteria may also produce catechol type when the medium $\mathrm{pH}$ is designed alkaline. A previous study reported that a bacterium produces hydroxamate, catechol or both at the same time (Grobelak and Hiller 2017).

\section{Quantitative siderophore production and growth curve}

This current study showed that the tested bacteria significantly produced high siderophore after 72 hours of incubation $(\mathrm{p}<0.05)$. However, the siderophore production of the tested bacteria was lower than that of the control (Pseudomonas aeruginosa) at early incubation time (0 to 48 hours). The highest siderophore produced by the tested bacteria was $62.90 \%$ (EI5 isolate) and $35.31 \%$ (EI6 isolate). The siderophore unit 


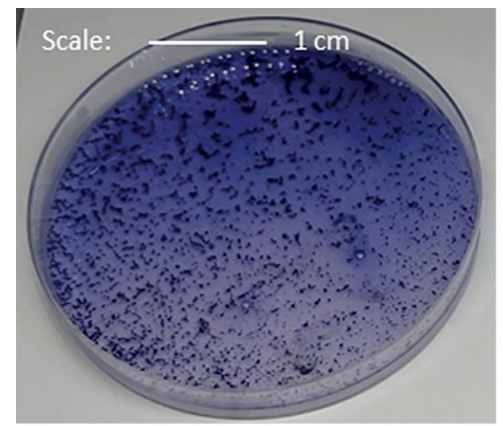

Control (-)

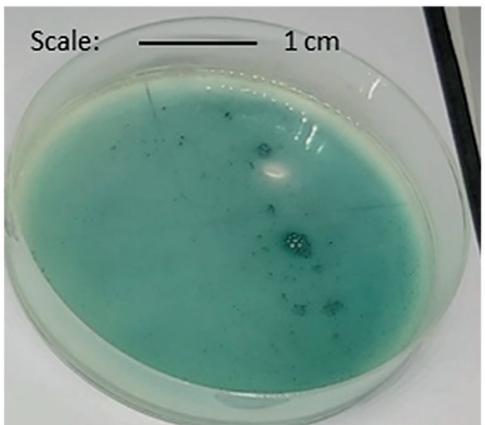

CD6 Isolate

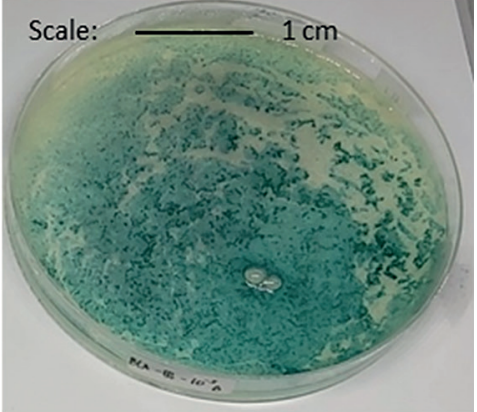

Control (+)

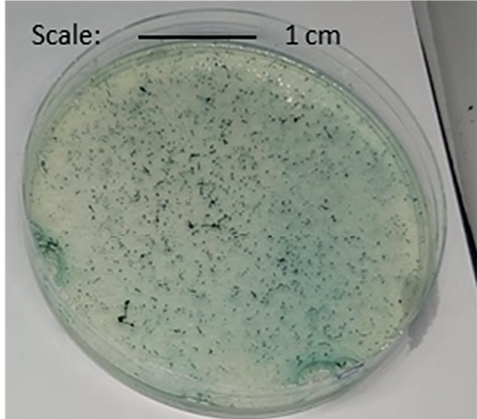

El6 Isolate

Figure 1. Qualitative siderophore production assay: control (-) = medium without bacteria inoculation; control $(+)=$ Pseudomonas aeruginosa known as hydroxamate type of siderophore-producing bacterium; $\mathrm{CD}=$ Cynodon dactylon; $\mathrm{EI}=$ Eleusine indica

produced by EI5 isolate was significantly higher than Pseudomonas aeruginosa (control positive), at the same incubation time ( 72 hours of incubation), namely $19.85 \%$ (Figure 2). A previous study reported that the siderophore unit produced by Pseudomonas aeruginosa is higher than other tested bacteria (Bacillus subtilis and Bacillus megatericus), namely $80.5 \%$ (Ghosh et al. 2015). The result was contrary to the current study because the growth medium was different. The maximum siderophore unit produced by Pseudomonas aeruginosa in the previous study by Ghosh et al. (2015) was achieved on MEB medium (Malt Extract Broth). However, the growth medium used in this study was a succinic acid medium.

The bacteria with siderophore-producing traits can potentially be applied in Hg phytoremediation due to the primary role of siderophore as a nutrient provider and $\mathrm{Hg}$ chelator (Rajkumar et al. 2010; Ahmed and Holmström 2014). Screening for the most potential siderophoreproducing bacteria is not only for producing a

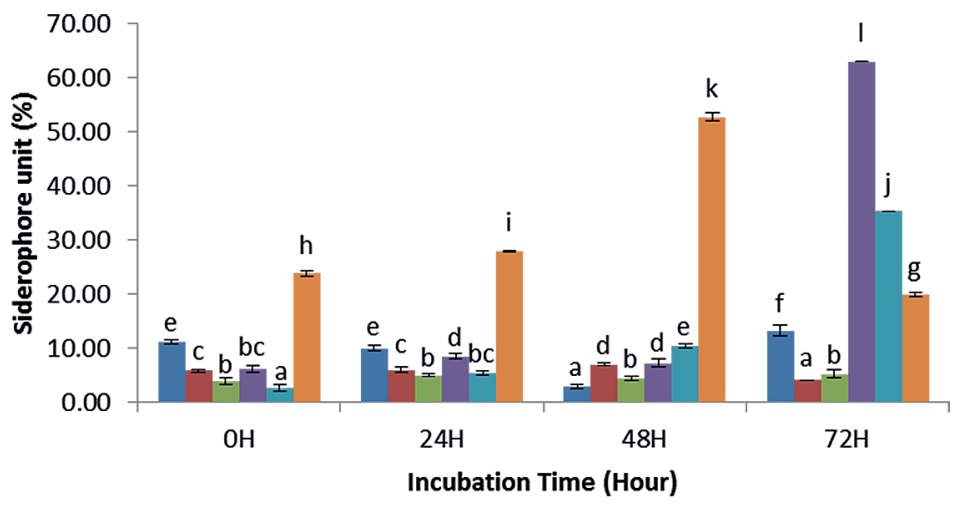

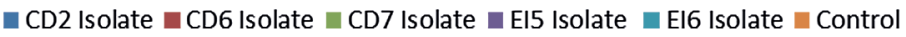

Figure 2. Siderophore production of tested isolates; $\mathrm{CD}=$ Cynodon dactylon; $\mathrm{EI}=$ Eleusine indica . Means with a different letter are significantly different $(\mathrm{P}<0.05)$ as determined by the Tukey's test. 
higher unit of siderophore but also the ability to produce a higher siderophore unit at a short incubation period. Generally, inoculation of endophytic bacteria to the plant part or plant seed is carried out after the bacteria were incubated for 24 hours (overnight incubation) (Pereira et al. 2007; Pereira et al. 2011). Thus, selecting the bacteria that produce high siderophore units after 24 hours of incubation (48 hours incubation) is essential. The tested bacteria that produced high siderophore units at 48 hours of incubation were the CD6 isolate (7.00\%), EI5 isolate (7.29\%), and EI6 isolate (10.35\%). Moreover, Pseudomonas aeruginosa produced the highest siderophore unit at 48 hours of incubation $(52.65 \%)$. This result indicates that the optimum incubation time for siderophore production is at 48 hours. A previous study also reported that siderophore production by Pseudomonas aeruginosa grown in the succinic medium reached maximum concentration around 42-48 of incubation time (Sasirekha and Srividya 2016).

The cell density of the tested bacteria peaked at 48 hours of incubation for CD6 isolate. However, the CD2, CD7, EI5 and EI6 isolates peaked at 72 hours after incubation (Figure 3). Sasirekha and Srividya (2016) reported that siderophore production increases in line with the increasing number of bacteria cells. The number of bacteria cells increases along with the concentration of iron in the medium (Sasirekha and Srividya 2016). However, the increasing iron concentration in the medium decreases siderophore production concentration by Pseudomonas aeruginosa (Sasirekha and Srividya 2016). This indicates that siderophore production by bacteria for scavenging iron occurs under limited iron conditions. Thus, inoculation of siderophore-producing bacteria for $\mathrm{Hg}$ phytoremediation can support plant growth in the Hg-contaminated soil with low nutrient availability. Rajkumar et al. (2010) stated that siderophores play a dual role in providing iron for the plant and protecting metal toxicity by reducing free radicals formation and protecting microbial auxins from oxidative degradation for promoting plant growth.

\section{Pathogenicity test}

Hemolysis analysis was conducted to screen the most potential endophytic bacteria for in-situ $\mathrm{Hg}$ phytoremediation. The hemolysis activity test was used to screen the potentially pathogenic bacteria for animals and humans when applied to the study site (Sudewi et al. 2020). The result showed that two of the five tested bacteria that survived in the NA medium containing more than $250 \mathrm{mg} / \mathrm{L}$ $\mathrm{HgCl}_{2}$ in the previous study (Ustiatik 2019) could not lyse hemoglobin (Table 2). There were no clear zone, or changes in colony color, around the CD6 and EI6 isolates inoculated on blood agar (Figure 4). The isolates which showed a negative result of the hemolysis test (the CD6 and EI6 isolates) will be used for phytoremediation on the $\mathrm{Hg}$-contaminated soil in the future study.

\section{Phenotypic characterization}

Non-pathogenic isolates (CD6 and EI6 isolates) were phenotypically characterized (Table 3 and Table 4). These isolates were gram-positive cocci (CD6 isolate) and bacilli (EI6 isolate). Both isolates were positively tested for catalase. The

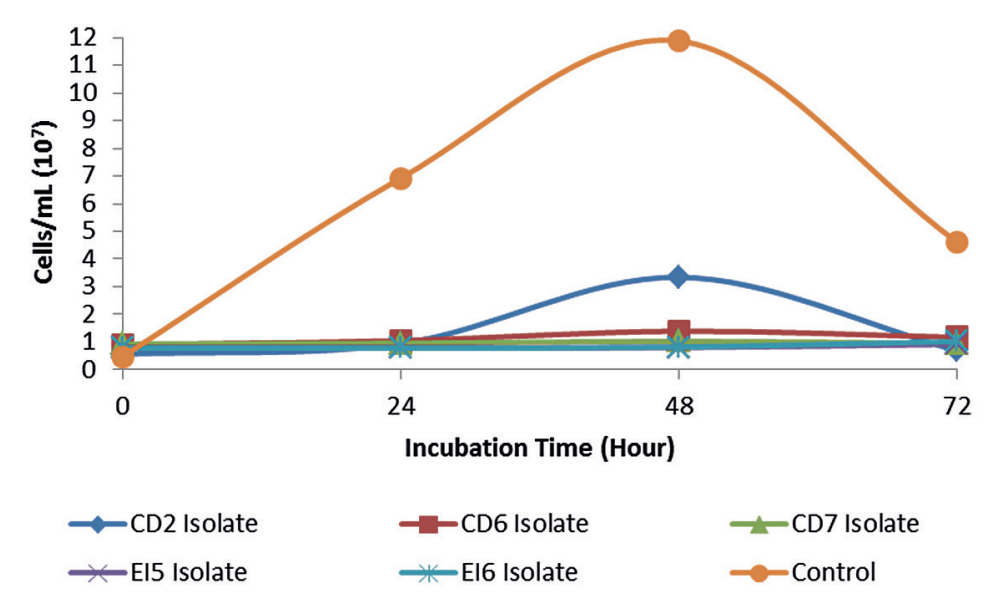

Figure 3. Growth curve of tested isolates; $\mathrm{CD}=$ Cynodon dactylon; $\mathrm{EI}=$ Eleusine indica 
Table 2. Hemolysis analysis of the tested bacteria

\begin{tabular}{|c|c|c|c|}
\hline Isolate & $\alpha$ & $\beta$ & $\gamma$ \\
\hline CD2 & & $\checkmark$ & \\
\hline CD6 & & & $\checkmark$ \\
\hline CD7 & & $\checkmark$ & \\
\hline EI5 & $\checkmark$ & & \\
\hline EI6 & & & $\checkmark$ \\
\hline
\end{tabular}

Note: $\gamma=$ No lysis of red blood cells; $\beta=$ Lysis of red blood cells with complete-destruction and use of hemoglobin by the organism; $\alpha=$ Incomplete lysis of red blood cells, with reduction of hemoglobin to methemoglobin; $\mathrm{CD}=$ Cynodon dactylon; $\mathrm{EI}=$ Eleusine indica

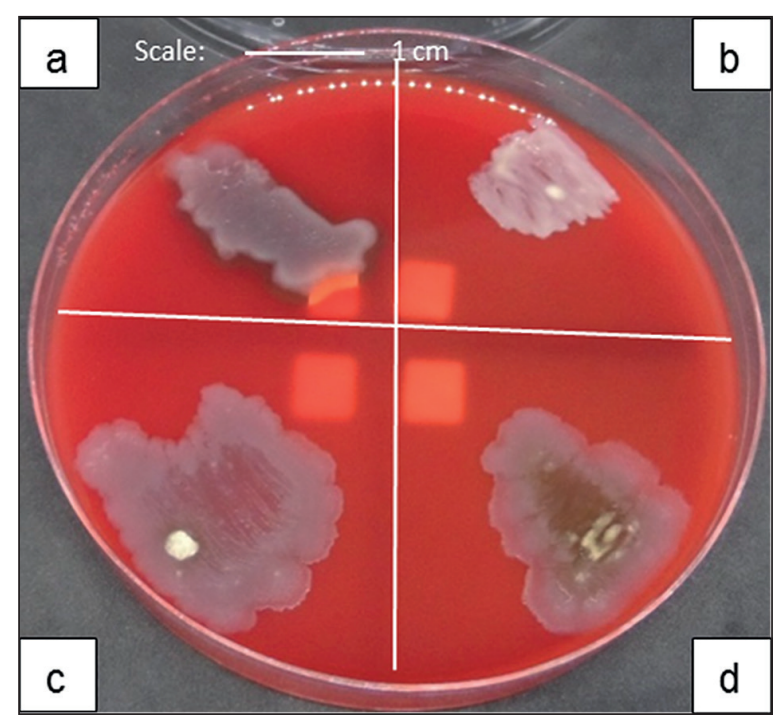

Figure 4. Hemolysis analysis: (a) control of $\beta$ hemolysis; (b) CD6 isolate; (c) = EI6 isolate (no lysis or $\gamma$ hemolysis); (d) control of $\alpha$ hemolysis; $\mathrm{CD}=$ Cynodon dactylon; $\mathrm{EI}=$ Eleusine indica

EI6 isolate was tested positive as spore-forming, motile, nitrate reduction, starch and casein hydrolysis; however, the CD6 isolate was the opposite. On the basis of the $16 \mathrm{~s}$ rDNA sequencing analysis in the previous study, the CD6 isolate is Jeotgalicoccus huakuii and the EI6 isolate is Bacillus amyloliquefaciens. Jeotgalicoccus huakuii was isolated from seaside soil (a halotolerant bacterium) in Shandong Province, China (type strain: $\left.\mathrm{NY}-2^{\mathrm{T}}\right)$. The optimal growth of this bacterium is at $28-37^{\circ} \mathrm{C}$ and unable to grow under $4^{\circ} \mathrm{C}$ or above $43^{\circ} \mathrm{C}$. The optimal $\mathrm{pH}$ for growth is $6.5-10.0$ and unable to grow below $\mathrm{pH} 4.5$. This species can grow in the presence of $0-23 \%(\mathrm{w} / \mathrm{v}) \mathrm{NaCl}$, with optimal growth at $3-8 \%(\mathrm{w} / \mathrm{v}) \mathrm{NaCl}$. This species can grow both under aerobic and anaerobic conditions (Guo et al. 2010).
Table 3. Phenotypic characterization of siderophoreproducing bacteria

\begin{tabular}{|c|c|c|}
\hline Parameter & CD6 Isolate & EI6 Isolate \\
\hline $\begin{array}{l}\text { Colony pigmentation: } \\
\text { cream/light yellow }\end{array}$ & + & + \\
\hline Colony diameter $(\mathrm{mm})$ : & & \\
\hline $0.00-2.00$ & + & + \\
\hline $2.01-3.00$ & - & - \\
\hline $3.01-4.00$ & - & - \\
\hline Colony shape: circular & + & + \\
\hline $\begin{array}{l}\text { Colony margin: } \\
\text { entire } \\
\text { undulate }\end{array}$ & + & $\begin{array}{l}- \\
+\end{array}$ \\
\hline Colony elevation: convex & + & + \\
\hline $\begin{array}{l}\text { Colony consistency: } \\
\text { shiny } \\
\text { dry }\end{array}$ & $\begin{array}{l}+ \\
-\end{array}$ & $\overline{+}+$ \\
\hline $\begin{array}{l}\text { Cell shape: } \\
\text { cocci } \\
\mathrm{rod} / \text { bacilli }\end{array}$ & + & - \\
\hline Gram reaction & + & + \\
\hline Spore formation & - & + \\
\hline Motility & - & + \\
\hline Oxidase & + & - \\
\hline Nitrate reduction & - & + \\
\hline Catalase & + & + \\
\hline Coagulase & + & - \\
\hline Novobiocin sensitivity & + & - \\
\hline Starch hydrolysis & - & + \\
\hline Casein hydrolysis & - & + \\
\hline $\begin{array}{l}\text { TSIA: } \\
\text { glucose } \\
\text { sucrose }\end{array}$ & - & $\begin{array}{l}+ \\
+\end{array}$ \\
\hline
\end{tabular}

Note: $(+)=$ positive reaction; $(-)=$ negative reaction; $\mathrm{CD}=$ Cynodon dactylon $; \mathrm{EI}=$ Eleusine indica; TSIA $=$ triple sugar iron agar.

On the basis of Bergey's Manual of Systemic Bacteriology Bacillus amyloliquefaciens is an aerobic bacterium that digests starch. The optimum growth temperature is $30-40^{\circ} \mathrm{C}$ and unable to grow below $15^{\circ} \mathrm{C}$ and above $50^{\circ} \mathrm{C}$. The species can grow in the presence of $5 \%$ $\mathrm{NaCl}$, and most strains tolerate $10 \% \mathrm{NaCl}$. The type strain of this species is DSM7 ATCC 23350 that was isolated from infested soil in Germany. Bacillus amyloliquefaciens was found as endophytic in healthy plants, including cotton, grape, peas, spruce, and sweet corn. The species has important growth promotion roles, including phytohormones production, increasing nutrient availability (nitrogen-fixing bacteria), ethylene production suppression, enhancement of root nodulation and plant protection such as 
Table 4. Phenotypic characterization of siderophoreproducing bacteria using biochemical identification kit

\begin{tabular}{|l|c|c|}
\hline \multicolumn{1}{|c|}{ Parameter } & CD6 Isolate & El6 Isolate \\
\hline Lysine & - & + \\
\hline Ornithine & - & - \\
\hline $\mathrm{H}_{2} \mathrm{~S}$ & - & - \\
\hline Glucose & & + \\
\hline Mannitol & - & + \\
\hline Xylose & - & - \\
\hline ONPG & - & + \\
\hline Indole & & + \\
\hline Urease & - & - \\
\hline V-P & + & + \\
\hline Citrate & - & + \\
\hline TDA & - & - \\
\hline Gelatine & - & + \\
\hline Malonate & - & - \\
\hline Inositol & - & - \\
\hline Sorbitol & - & - \\
\hline Rhamnose & - & + \\
\hline Sucrose & - & - \\
\hline Lactose & - & - \\
\hline Arabinose & - & - \\
\hline Adonitol & - & - \\
\hline Raffinose & - & - \\
\hline Salicin & - & - \\
\hline Arginine & - & - \\
\hline Note: & - & - \\
\hline
\end{tabular}

Note: $\mathrm{ONPG}=$ ortho-nitrophenyl- $\beta$-galactoside; $\mathrm{V}-\mathrm{P}=$ voges proskauer; TDA $=$ tryptophan deaminase $(+)=$ positive reaction; $(-)=$ negative reaction; $\mathrm{CD}=$ Cynodon dactylon; $\mathrm{EI}=$ Eleusine indica

biocontrol agents of plant diseases by various mechanisms, including the production of antibiotics (Vos et al. 2009).

\section{CONCLUSIONS}

All tested isolates were positive as siderophore-producing bacteria and the siderophore type was hydroxamate. The highest siderophore production was obtained for the EI5 and EI6 isolates (62.90\% and $35.31 \%$, respectively) isolated from Eleusine indica at 72 hours of incubation. In turn, the CD6, EI5 and EI6 isolates achieved high siderophore production at a short incubation period (48 hours). However, during the hemolysis test, only the CD6 and EI6 isolates were negatively tested for hemoglobin lysis. The isolates that showed a negative result of the hemolysis test will be used for phytoremediation on the $\mathrm{Hg}$-contaminated soil in the future study.

\section{Acknowledgment}

This research was funded by the Ministry of Research and Technology/National Agency for Research and Innovation of Indonesia through Masters and $\mathrm{PhD} / \mathrm{PMDSU}$ Scholarship Programmes. The authors thank field and laboratory assistants in Indonesia, $\mathrm{PhD}$ fellows at Brawijaya and the Bonjeruk Farmers Association of Central Lombok, West Nusa Tenggara, Indonesia for their support.

\section{REFERENCES}

1. Ahmed, E. and S. J. M. Holmström. 2014. Siderophores in environmental research: Roles and applications, Microb. Biotechnol., 7(3), 196-208.

2. Ali, S. S. and N. N. Vidhale. 2016. Bacterial Siderohore and their Application : A review Review Article Bacterial Siderophore and their Application : A review, 2(January), 303-312.

3. Bharucha, U. D., K. C. Patel, and U. B. Trivedi. 2013. Antifungal activity of catecholate type siderophore produced by Bacillus sp, Int. J. Res. Pharm. Sci., 4(4), 528-531.

4. Cappuccino, J. G. and S. Natalie. 2014. Cultivation of Microorganisms: Nutritional and Physical Requirements, and Enumeration of Microbial Populations, Pearson Education, New York.

5. Dash, H. R. and S. Das. 2014. Bioremediation potential of mercury by Bacillus species isolated from marine environment and wastes of steel industry, Bioremediation Journal 18 (3), 204-212:sêpi, $\mathrm{K}$. and Y. Ismawati. 2015. Inventory of mercury releases in indonesia, Proc. The 5th Environmental Technology and Management Conference "Green Technology towards Sustainable Environment, 1-8.

6. Falandysz, J., J. Zhang, Y. Z. Wang, M. Saba, G. Krasińska, A. Wiejak, T. Li. 2015. Evaluation of mercury contamination in fungi boletus species from latosols, lateritic red earths, and red and yellow earths in the circum-pacific mercuriferous belt of southwestern China, PLoS One, 10(11), 1-19.

7. Franchi, E., E. Rolli, R. Marasco, G. Agazzi, S. Borin, P. Cosmina, F. Pedron, I. Rosellini, M. Barbafieri, G. Petruzzelli. 2017. Phytoremediation of a multi contaminated soil: mercury and arsenic phytoextraction assisted by mobilizing agent and plant growth-promoting bacteria, J. Soils Sediments, 17(5), 1224-1236. 
8. Ghosh, S. K., S. Pal, and N. Chakraborty. 2015. The qualitative and quantitative assay of siderophore production by some microorganisms and effect of different media on its production, Int. J. Chem. Sci., 13(4), 1621-1629.

9. Glick, B. R. 2012. Plant Growth-Promoting Bacteria : Mechanisms and Applications, 2012, 1-15.

10. Grobelak, A. and J. Hiller. 2017. Bacterial siderophores promote plant growth: Screening of catechol and hydroxamate siderophores, Int. J. Phytoremediation, 19(9), 825-833.

11. Guo, X. Q., R. Li, L. Q. Zheng, D. Q. Lin, J. Q. Sun, S. P. Li, W. J. Li, and J. D. Jiang, 2010, Jeotgalicoccus Huakuii Sp. Nov., a Halotolerant Bacterium Isolated from Seaside Soil, International Journal of Systematic and Evolutionary Microbiology, 60(6), 1307-10.

12. Ijaz, A., A. Imran, M. Anwar ul Haq, Q. M. Khan, and M. Afzal. 2016. Phytoremediation: recent advances in plant-endophytic synergistic interactions, Plant Soil, 405(1-2), 179-195.

13. Jabeen, H., S. Iqbal, F. Ahmad, M. Afzal, and S. Firdous. 2016. Enhanced remediation of chlorpyrifos by ryegrass (Lolium multiflorum) and a chlorpyrifos degrading bacterial endophyte Mezorhizobium sp. HN3, Int. J. Phytoremediation, 18(2), 126-133.

14. Jenifer, C. A. and A. S. Sharmili. 2015. Studies on siderophore production by microbial isolates obtained from aquatic environment, Pelagia Res. Libr. Eur. J. Exp. Biol., 5(10), 41-45.

15. Khan, L. B., S. Swift, T. Kamal, and H. M. Read. 2018. Simulation of MICROBACT Strip Assay Using Colored Liquids to Demonstrate Identification of Unknown Gram-Negative Organisms in Undergraduate Laboratory, J. Microbiol. Biol. Educ., 19(2), 19-22.

16. Kong, Z.and B. R. Glick. 2017. Chapter 2: The Role of Plant Growth- Promoting Bacteria in Metal Phytoremediation Zhaoyu, Advances in Microbial Physiology, 71(August), 327-353.

17. Leguizamo, M. A. O., W. D. F. Gómez, and M. C. G. Sarmiento. 2017. Native herbaceous plant species with potential use in phytoremediation of heavy metals, spotlight on wetlands - A review, Chemosphere, 168, 1230-1247.

18. Leung, H. M., Z. W. Wang, Z. H. Ye, K. L. Yung, X. L. Peng, and K. C. Cheung. 2013. Interactions between arbuscular mycorrhizae and plants in phytoremediation of metal-contaminated soils: A review, Pedosphere, 23(5), 549-563.

19. Manoj, S. R., C. Karthik b, K. Kadirvelu, P. I. Arulselvi, T. Shanmugasundaram, B. Bruno, M. Rajkumar. 2020. Understanding the molecular mechanisms for the enhanced phytoremediation of heavy metals through plant growth promoting rhizobacteria: A review, J. Environ. Manage., 254(2020) 109779 .
20. Manwar, A. V., S. R. Khandelwal, B. L. Chaudhari, J. M. Meyer, and S. B. Chincholkar. 2004. Siderophore production by a marine Pseudomonas aeruginosa and its antagonistic action against phytopathogenic fungi, Appl. Biochem. Biotechnol.-Part A Enzym. Eng. Biotechnol., 118(1-3), pp. 243-251.

21. Meyer, J. M. and M. A. Abdallah. 1978. The fluorescent pigment of Pseudomonas fluorescens: Biosynthesis, purification and physicochemical properties, J. Gen. Microbiol., 107(2), 319-328.

22. Murtado, A., N. R. Mubarik, and A. Tjahjoleksono. 2020. Isolation and characterization endophytic bacteria as biological control of fungus Colletotrichum sp. on onion plants (Allium cepa L.), IOP Conf. Ser. Earth Environ. Sci., 457( 1).

23. Padmavathiamma, P. K. and L. Y. Li. 2007. Phytoremediation technology: Hyper-accumulation metals in plants, Water. Air. Soil Pollut., 184(1-4), 105-126.

24. Pereira, P., A. Nesci, and M. Etcheverry. 2007. Effects of biocontrol agents on Fusarium verticillioides count and fumonisin content in the maize agroecosystem: Impact on rhizospheric bacterial and fungal groups, Biol. Control, 42(3), 281-287.

25. Pereira, P., S. G. Ibáñez, E. Agostini, and M. Etcheverry. 2011. Effects of maize inoculation with Fusarium verticillioides and with two bacterial biocontrol agents on seedlings growth and antioxidative enzymatic activities, Appl. Soil Ecol., 51(1), 52-59.

26. Pérez-Miranda, S., N. Cabirol, R. George-Téllez, L. S. Zamudio-Rivera, and F. J. Fernández. 2007. O-CAS, a fast and universal method for siderophore detection, J. Microbiol. Methods, 70(1), 127-131.

27. Prescott, H. 2002. Laboratory exercises in microbiology, Lab. Exerc. Microbiol., 117-124.

28. Rajkumar, M., N. Ae, M. N. V. Prasad, and H. Freitas. 2010. Potential of siderophore-producing bacteria for improving heavy metal phytoextraction, Trends Biotechnol., 28(3), 142-149.

29. Ruiz, O. N., D. Alvarez, C. Torres, L. Roman, and H. Daniell. 2011. Metallothionein expression in chloroplasts enhances mercury accumulation and phytoremediation capability, Plant Biotechnol. J., 9 (5), 609-617.

30. Sasirekha, B. and S. Srividya. 2016. Siderophore production by Pseudomonas aeruginosa FP6, a biocontrol strain for Rhizoctonia solani and Colletotrichum gloeosporioides causing diseases in chilli, Agric. Nat. Resour., 50(4), 250-256.

31. Schütze, E., E. Ahmed, A. Voit, M. Klose, M. Greyer, A.Svatoš, D. Merten, M. Roth, S. J. M. Holmström, E. Kothe. 2015. Siderophore production by streptomycetes-stability and alteration of ferrihydroxamates in heavy metal-contaminated soil, Environ. Sci. Pollut. Res., 22(24), 19376-19383. 
32. Schwyn, B. and J. B. Neilands. 1987. Universal chemical assay for the detection and determination of siderophore, Anal. Biochem., 160, 47-56.

33. Shao, B., J. Luo, M. He, L. Tian, W. H, L. Xu, Z. Zhang, Y. 2020. Ecological risk assessment at the food web scale: A case study of a mercury contaminated oilfield, Chemosphere, 260(127559), 1-10.

34. Sheng, X. F., J. J. Xia, C. Y. Jiang, L. Y. He, and M. Qian. 2008. Characterization of heavy metalresistant endophytic bacteria from rape (Brassica napus) roots and their potential in promoting the growth and lead accumulation of rape, Environ. Pollut., 156(3), 1164-1170.

35. Sudewi, S., A. Ala, Baharuddin, and M. Farid. 2020. The isolation, characterization endophytic bacteria from roots of local rice plant kamba in, Central Sulawesi, Indonesia, Biodiversitas, 21(4), 1614-1624.

36. Tangahu, B. V., S. R. Sheikh Abdullah, H. Basri, M. Idris, N. Anuar, and M. Mukhlisin. 2011. A review on heavy metals $(\mathrm{As}, \mathrm{Pb}$, and $\mathrm{Hg}$ ) uptake by plants through phytoremediation, Int. J. Chem. Eng., 2011(2011), 1-31.

37. Trihadiningrum, Y., R. A. Latif, and R. M. Rachman. 2019. Speciation of mercury contaminant in public gold mine tailing and its stabilization using sulfur and sulfide, J. Ecol. Eng., 20(4), 29-34.
38. Ustiatik, R. 2019. Potensi bakteri endofit resisten merkuri pada rumput lokal di tanah tercemar merkuri sebagai plant growth promoting bacteria (PGPB) (in Bahasa Indonesia). Thesis. Brawijaya University.

39. Ustiatik, R., S. Nurfitriani, A. Fiqri, and E. Handayanto. 2020. The Use of Mercury-Resistant Bacteria to Enhance Phytoremediation of Soil Contaminated with Small-Scale Gold Mine Tailing, Nature Environment and Pollution Technology, 19(1), 253-61.

40. Vos, P. D, G. M. Garrity, D. Jones, N.R. Krieg, W. Ludwig, F. A. Rainey, K. H. Schleifer, and W. B. Whitman, eds. 2009. Bergey's Manual of Systemic Bacteriology. Vol. 3. 2nd ed. Athens: Springer US.

41. Xu, J., A. G. Bravo, A. Lagerkvist, S. Bertilsson, R. Sjöblom, and J. Kumpiene, 2015. Sources and remediation techniques for mercury contaminated soil, Environ. Int., 74 (2015), 42-53.

42. Yan, X., Z. Wang, Y. Mei, L. Wang, X. Wang, Q. $\mathrm{Xu}, \mathrm{S}$. Peng, Y. Zhou and C. Wei. 2018. Isolation, diversity, and growth-promoting activities of endophytic bacteria from tea cultivars of Zijuan and Yunkang-10, Front. Microbiol., 9( JUL), 1-11.

43. Zhang Y., X. Yu, W. Zhang, D. Lang, X. Zhang, G. Cui and X. Zhang. 2019. Interactions between Endophytes and Plants: Beneficial Effect of Endophytes to Ameliorate Biotic and Abiotic Stresses in Plants, J. Plant Biol., 62(1), 2014-2015. 